\title{
Sensitivity Analysis of Carbonate Looping Process Using Twin Fluidized Bed Model
}

\author{
Xuan Yang ${ }^{1}$, Yishu Qiao ${ }^{1}$, Xiangyang Han ${ }^{1}$, Bingcheng Liu ${ }^{1,2 *}$, Kinjal J. Shah ${ }^{3}$, \\ Pen-Chi Chiang ${ }^{4}$
}

\author{
${ }^{1}$ Qingdao University of Science and Technology, Qingdao 266061, China \\ 2 Institute of Climate \& Energy Sustainable Development, Qingdao 266061, China \\ ${ }^{3}$ College of Urban Construction, Nanjing Tech University, Nanjing 211816, China \\ ${ }^{4}$ Carbon Cycle Research Center, National Taiwan University, Taipei 10672, Taiwan
}

\begin{abstract}
$\mathrm{CO}_{2}$ as the major greenhouse gas plays an important role in environmental problems. Therefore, it is reasonable to find an effective technology for mitigating large $\mathrm{CO}_{2}$ emissions. Carbonating looping is an efficient post-combustion $\mathrm{CO}_{2}$ capture technology using limestone sorbent, which is more energy-saving than traditional technologies. In our research, a carbonate looping process model had been developed using ASPEN PLUS software. In detail, the sensitivity analysis of main parameters were adopted. The simulation results indicated that the $\mathrm{CO}_{2}$ capture rate of the whole process can achieve above $90 \%$ and $\mathrm{CO}_{2}$ concentration in the decarbonated flue gas was less than $4 \%$ under the carbonation temperature, the calcination temperature, the $\mathrm{F}_{0} / \mathrm{F}_{\mathrm{CO} 2}$ and the gas-solid separation were $630^{\circ} \mathrm{C}, 900^{\circ} \mathrm{C}, 0.04,1.0$, separately. This work gave an potential example for the retrofitting current coal-fired power plant combined with carbonate looping process.
\end{abstract}

Keywords: $\mathrm{CO}_{2}$ capture; Carbonate looping; Process model; Twin Fluidized bed; Sensitivity analysis.

\section{INTRODUCTION}

In recent years, scientists and researchers have put much more concern on the climate change issues, which surely confirm that global warming is mainly caused by greenhouse gas emission (GHG) (Safdarnejad et al., 2016; Cheng et al., 2019; Huang et al., 2019). GHG is mainly emitted from fossil fuel burning which is considered as the main source of global warming. Among all the $\mathrm{GHG}, \mathrm{CO}_{2}$ is the principal gas which related to many large power plants (Symonds et al., 2017; Tritippayanon et al., 2019; Safarian et al., 2020). Therefore, it is necessary to develop effective technologies for reducing large $\mathrm{CO}_{2}$ emissions (Li et al., 2013; Jiang et al., 2019). $\mathrm{CO}_{2}$ capture and storage (CCS) is a promising technology to control GHG discharge, which has been widely used in these decades (Zhang et al., 2019; Liu et al., 2020). There are several methods for $\mathrm{CO}_{2}$ capture from power plants: (i) oxy-fuel combustion (Atsonios et al., 2015); (ii) precombustion (Solares et al., 2020); (iii) post-combustion (Alam et al., 2020). The post-combustion method is widely used method for $\mathrm{CO}_{2}$ capture in power stations at present. The

\footnotetext{
${ }^{*}$ Corresponding author.

Tel.: (+86) 17852726882

E-mail address: liubingchengqust@163.com
}

flue gas passes through $\mathrm{CO}_{2}$ removal equipment to mitigate $\mathrm{CO}_{2}$ emission (Liang et al., 2015; Martinez et al., 2018).

There have been many methods in the literature about post-combustion $\mathrm{CO}_{2}$ captures, such as absorption (Porter et al., 2015), adsorption (Shah and Imae, 2016), cryogenic (Yuan et al., 2014), chemical looping (Leion et al., 2008) and membrane (Zhao et al., 2018; Yang et al, 2019). However, these processes have some bottlenecks including enormous energy losses of $8-14 \%$ which increase fuel consumption and environmental concern regarding solvent regeneration (Lasheras et al., 2011; Oh et al., 2016; Liu et al., 2019a, b). In addition, some researchers have proposed that the chemical looping combustion consumes less energy to separate $\mathrm{CO}_{2}$ from flue gas, but this method still need full-scale experimental development (Abad et al., 2007; Leion et al., 2008). The carbonate looping (CL) is one of the promising methods for post-combustion $\mathrm{CO}_{2}$ capture, which uses calcium oxide $(\mathrm{CaO})$ as absorption sorbents to reduce $\mathrm{CO}_{2}$ emission (Diego et al., 2017). The main equipment of this process is two interconnected fluidized beds. The principal of the carbonate looping process is shown in Fig. 1.

In Fig. 1, the flue gas which comes from an upstream power plant firstly enters the carbonator. In the carbonator, most of the $\mathrm{CO}_{2}$ react with $\mathrm{CaO}$ and convert to $\mathrm{CaCO}_{3}$. The exothermic carbonation reaction happens at $650^{\circ} \mathrm{C}$ and a pressure of 1 bar which can achieve a better conversion rate of $\mathrm{CaO}$ (Strohle et al., 2014). The $\mathrm{CaCO}_{3}$ then transfers to 


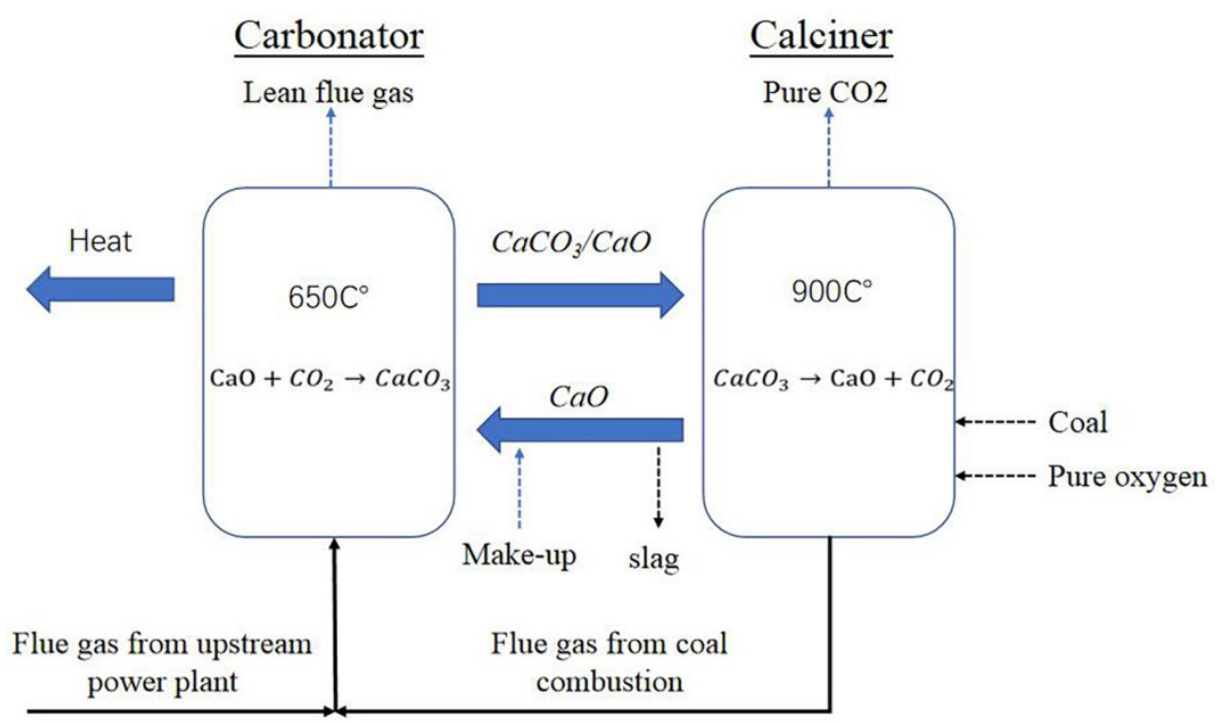

Fig. 1. Carbonate looping process principle.

the second fluidized bed (calciner), where the $\mathrm{CO}_{2}$ is released from $\mathrm{CaCO}_{3}$ at about $950^{\circ} \mathrm{C}$, forming high purity $\mathrm{CO}_{2}$ product and ready to compress for storage. The regenerated $\mathrm{CaO}$ from calcination reaction is then sent to the carbonator for another cycle. The calcination reaction is endothermic, therefore the extra heat is supplied by the combustion of fuel and pure oxygen. In the whole process, high temperature will cause deactivation of sorbent and the over-time cycle will also lead to solid losses. Therefore, make-up flow should be introduced into the system to keep the mass balance in the system (Jia et al., 2007; Zhang et al., 2016; Alonso et al., 2018). Compared with other post-combustion $\mathrm{CO}_{2}$ capture technologies, CL has extremely lower energy penalties and the sorbent is widely distributed in nature and easy to obtain (Romano, 2009; Pan et al., 2017). In addition, CL using indirectly heated method will be further improving $\mathrm{CO}_{2}$ capture efficiency (Hoeftberger et al., 2016; Reitz et al., 2016).

The feasibility of the CL process has been evaluated by many researchers through large-scale test rigs and simulations. In 2009, Symonds et al. (2009) testified that humid environment can increase carbonation conversion. In 2010, Alonso et al. (2010) designed and built a $30 \mathrm{MW}_{\text {th }}$ test facility in Spain, and conducted a series of experiments about $\mathrm{CO}_{2}$ capture performance. The results showed that $\mathrm{CO}_{2}$ capture efficiency can be achieved above $70 \%$ as the reactors had enough solid inventory. A $10 \mathrm{~kW}_{\text {th }}$ dual fluidized bed (DFB) was erected in the University of Stuttgart (Germany) by Charitos et al. (2010). Some parameters, such as carbonate temperature, calcium looping ratio, and carbonation reaction time, etc., were investigated through this experiment. The experiments demonstrated that the increased carbonate temperature and calcium looping ratio can significantly boost $\mathrm{CO}_{2}$ capture efficiency, meanwhile, the $\mathrm{CO}_{2}$ capture efficiency of the whole system can reach above $90 \%$. On the other hand, Lasheras et al. (2011) developed a process model using a 1D fluidized bed model through ASPEN PLUS and Strohle et al. (2014) established a $1 \mathrm{MW}_{\text {th }}$ test rig to validate the simulation. These two works showed that make-up flow had a great influence on the $\mathrm{CO}_{2}$ absorption rate and the experiment had a great agreement with simulation. In 2019, Hilz et al. (2019) established a $20 \mathrm{MW}_{\text {th }}$ CL demonstration power plant, which showed good prospects for both economical and technical applications.

Present work focused on $\mathrm{CO}_{2}$ capture using carbonate looping based on earlier reported work by Shimizu et al. (1999). The flue gas came from $350 \mathrm{MW}_{\text {th }}$ net electrical power, which had a high temperature and flow rate. The whole process was introduced and set up into ASPEN PLUS software for numerical simulation of $\mathrm{CO}_{2}$ capture performance. The carbonation and calcination temperature, make-up flow, gas-solid separation efficiency, and $\mathrm{SO}_{2}$ concentration in the flue gas were analyzed and optimal parameters were obtained. The work will provide important data for the application of carbonate looping.

\section{METHODOLOGY}

\section{Model Description}

In the present research, a carbonate looping process model was established using ASPEN PLUS software and the process flow diagram was demonstrated as shown in Fig. 2. A coal-fired power plant that has $350 \mathrm{MW}_{\text {th }}$ net electrical power and $36 \%$ net efficiency was used as an upstream plant in this study. The sulfur dioxide gas was removed when the flue gas passed through the carbonate looping process. The main parameters of flue gas were shown in Table 1.

The flue gas initially entered the carbonator and the two chemical reactions occurred in carbonator:

$\mathrm{CaO}+\mathrm{CO}_{2} \rightarrow \mathrm{CaCo}_{3}$

$\mathrm{CaO}+\mathrm{SO}_{2}+(1 / 2) \mathrm{O}_{2} \rightarrow \mathrm{CaCo}_{4}$

The $\mathrm{CO}_{2}$ absorption reaction (R1) happened in the first fluidized bed (CARBONATE) and the $\mathrm{SO}_{2}$ absorption reaction rate (R2) was set as $100 \%$. The solid stream and the 


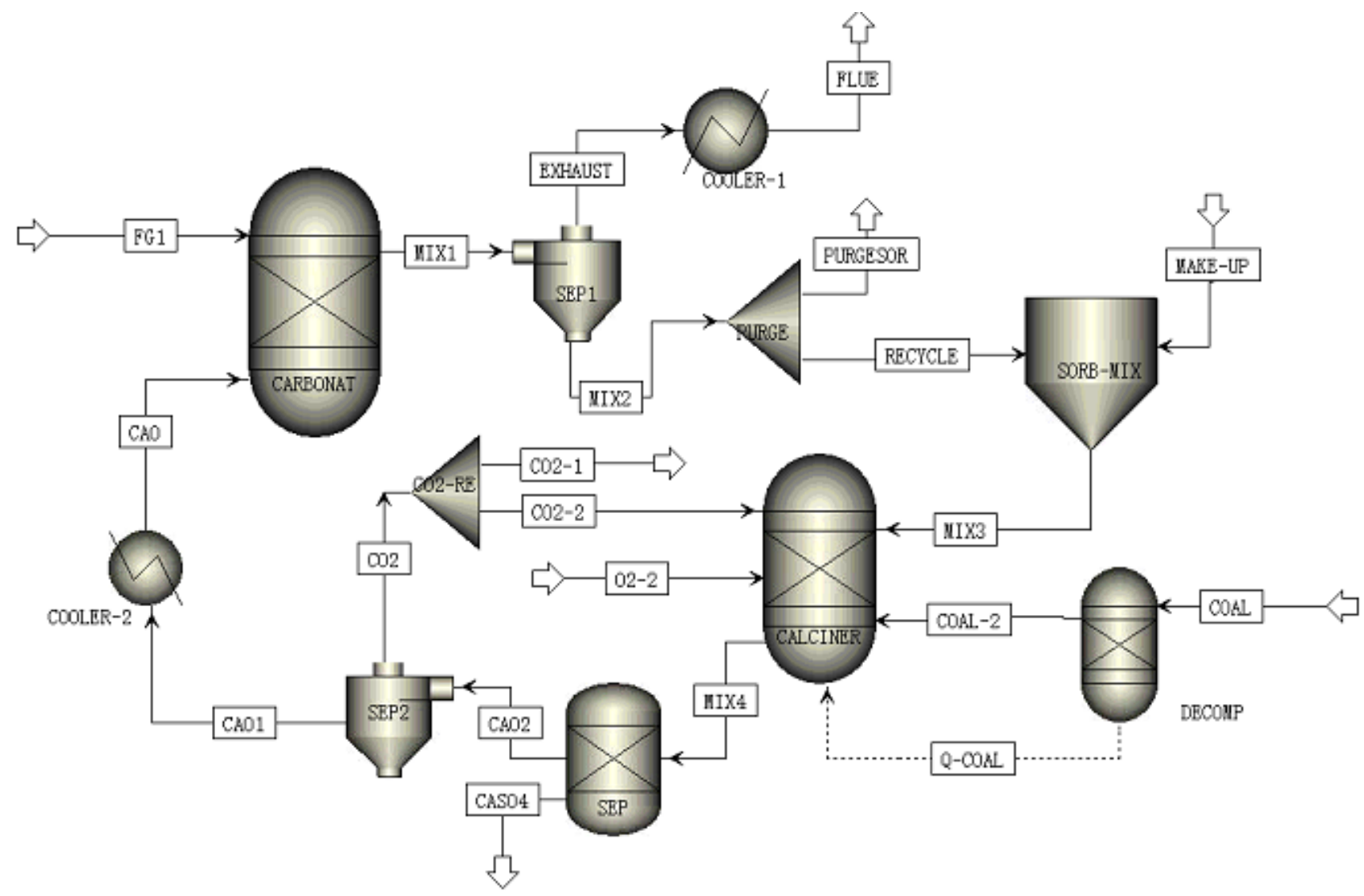

Fig. 2. A process model of carbonate looping in ASPEN PLUS.

Table 1. The properties of the flue gas.

\begin{tabular}{ll}
\hline Main parameters & Value \\
\hline Mass flow $\left(\mathrm{kg} \mathrm{s}^{-1}\right)$ & 446 \\
Temperature $\left({ }^{\circ} \mathrm{C}\right)$ & 120 \\
Pressure $(\mathrm{kPa})$ & 101.325 \\
Component of flue gas & Mass fraction $(\mathrm{wt} \%)$ \\
$\mathrm{CO}_{2}$ & 19.4 \\
$\mathrm{~N}_{2} \mathrm{O}$ & 15.53 \\
$\mathrm{SO}_{2}$ & 0.1 \\
$\mathrm{O}_{2}$ & 2.478 \\
$\mathrm{~N}_{2}$ & 62.64 \\
\hline
\end{tabular}

decarbonated flue gas were separated by the cyclone (SEP1), in which gas-solid efficiency was $100 \%$. After separation, the decarbonated flue gas was cooled down to around $100^{\circ} \mathrm{C}$ (COOLER-1) and discharged directly into the atmosphere. On the other hand, the solids were partly removed from the system (PURGE) due to the deactivation of sorbent and the rest solids were transferred into the calcinator (CALCINER).

In the calcinator, the reversed reaction happened at around $900^{\circ} \mathrm{C}$ and $\mathrm{CO}_{2}$ released from $\mathrm{CaCO}_{3}$. Because the reversed reaction was endothermic, the whole system needed external heat, which we adopted coal combustion to supply the heat. The coal was first pulverized into powder (DECOMP) and pushed into the calcinator to combust with pure oxygen. Meanwhile, the make-up flow (MAKE-UP) consisted of $100 \% \mathrm{CaCO}_{3}$ continually entered the calcinator for the supplement of emitted sorbent, which made sure the mass balance of the whole process.

After the reaction in the calcinator, the stream passed through the separator (SEP) first to discharge the $\mathrm{CaSO}_{4}$, the rest stream then flowed to the second cyclone (SEP2), where the $\mathrm{CO}_{2}$ of the whole system was separated from the solid and part of the $\mathrm{CO}_{2}(\mathrm{CO} 2-2)$ was recycled to the calcinator, the another was compressed for storage. Meanwhile, the $\mathrm{CaO}$ sorbent was sent into the carbonator for another cycle.

\section{Simulation Assumptions}

The simulation of the carbonate looping process was based on ASPEN PLUS and the main equipment parameters were shown in Table 2. To simplify the calculation, the following assumptions were adopted: (1) The reaction time did not affect the whole process; (2) There was no pressure loss in the whole process; (3) The combustion of coal was complete; (4) The by-product (ash and $\mathrm{CaSO}_{4}$ ) was completely extracted from the process.

Table 2. Main equipment parameters.

\begin{tabular}{lll}
\hline Main equipment & Items & Value \\
\hline Carbonator & Temperature $\left({ }^{\circ} \mathrm{C}\right)$ & 650 \\
Calcinator & Temperature $\left({ }^{\circ} \mathrm{C}\right)$ & 900 \\
& Make-up flow $\left(\mathrm{kmol} \mathrm{h}^{-1}\right)$ & 355 \\
& Coal flow $\left(\mathrm{t} \mathrm{h}^{-1}\right)$ & 120 \\
Cyclone & Separation efficiency $(\%)$ & 100 \\
\hline
\end{tabular}




\section{Process Evaluation}

To evaluate the performance of the whole carbonate looping process, two main indexes were introduced into this work: $\mathrm{CO}_{2}$ capture in the carbonator, and $\mathrm{CO}_{2}$ capture in the whole process. The calculation of these two indexes was summarized as follows:

$$
X_{\text {carb }}=1-\frac{\mathrm{CO}_{2, \text { flueout }}}{\mathrm{CO}_{2, \text { fluegas }}}
$$

The $\mathrm{CO}_{2}$ capture rate in the carbonator, $\mathrm{X}_{\text {carb, was defined }}$ as the relationship between $\mathrm{CO}_{2}$ concentration in the decarbonate flue gas, $\mathrm{CO}_{2}$, flue out, and the $\mathrm{CO}_{2}$ concentration in the flue gas, $\mathrm{CO}_{2}$, flue gas.

$$
X_{\mathrm{CO} 2}=\frac{\mathrm{CO}_{2, \text { captured }}}{\mathrm{CO}_{2, \text { fluegas }}+\mathrm{CO}_{2, \text { makeup }}+\mathrm{CO}_{2, \text { coal }}}
$$

The $\mathrm{CO}_{2}$ adsorption efficiency in the whole process, $X_{\mathrm{CO} 2}$, was explained as the relationship between captured $\mathrm{CO}_{2}$, and produced $\mathrm{CO}_{2}$. The produced $\mathrm{CO}_{2}$ mainly contained two parts: the make-up flow, $\mathrm{CO}_{2}$, make up, and the combustion of the coal, $\mathrm{CO}_{2}$, coal.

\section{RESULTS AND DISCUSSION}

\section{Effect of Carbonation Temperature}

Carbonation temperature had an effect on the $\mathrm{CO}_{2}$ capture rate which had been presented in Fig. 3. The basic simulation conditions were shown in Tables 1 and 2 .

In Fig. 3, with increasing carbonation temperature from 600 to $650^{\circ} \mathrm{C}$, the $\mathrm{CO}_{2}$ capture rate in carbonator increased steadily first and then dropped sharply to $82 \%$. For $\mathrm{CO}_{2}$ concentrations in the decarbonated flue gas, when carbonation temperature increased, it decreased firstly and then increased rapidly. This trend showed that high carbonation temperature can boost the conversion rate of the absorption reaction (R1), which was a benefit for $\mathrm{CO}_{2}$ capture. When the carbonation temperature was $630^{\circ} \mathrm{C}$, the $\mathrm{CO}_{2}$ capture rate in the carbonator reached the highest value which was $90 \%$ and $\mathrm{CO}_{2}$ concentration in the decarbonated flue gas was $2.5 \%$ which was the lowest point. However, the higher carbonation temperature was not good for the $\mathrm{CO}_{2}$ capture. When the temperature was above $630^{\circ} \mathrm{C}$, the over-high temperature had a bad effect on both the $\mathrm{CO}_{2}$ capture rate and $\mathrm{CO}_{2}$ concentrations in the flue gas. That was because $\mathrm{CaO}$ absorption was an exothermic reaction and higher temperature was detrimental to the adsorption reaction.

The effect of carbonation temperature on $\mathrm{CO}_{2}$ capture of the whole process and $\mathrm{CaCO}_{3}$ circulating flow rate were shown in Fig. 4 and obtained parameters were represented in Tables 1 and 2. It can be seen from Fig. 4 that the $\mathrm{CO}_{2}$ capture rate of the whole process and $\mathrm{CaCO}_{3}$ circulating flow rate had the same trend when the carbonation temperature was increased from 600 to $650^{\circ} \mathrm{C}$. The increasing carbonation temperature had two contrary effects. On the one hand, when the temperature increased from 600 to $630^{\circ} \mathrm{C}$, more $\mathrm{CO}_{2}$ was captured and more limestones were generated and circulated in the whole process, therefore, both $\mathrm{CO}_{2}$ capture rate and $\mathrm{CaCO}_{3}$ circulating flow grew. On the other hand, over-high temperature hindered the absorption reaction rate. That was why both two lines dropped sharply when the temperature increased from 630 to $650^{\circ} \mathrm{C}$. From the obtained results, it was concluded that the carbonation temperature significantly affected the performance of the process. Meanwhile, when the carbonation temperature was $630^{\circ} \mathrm{C}$, the $\mathrm{CO}_{2}$ capture rate and $\mathrm{CaCO}_{3}$ circulating flow rate had the highest value. So, we chose $630^{\circ} \mathrm{C}$ as the optimal carbonation temperature for further considerations.

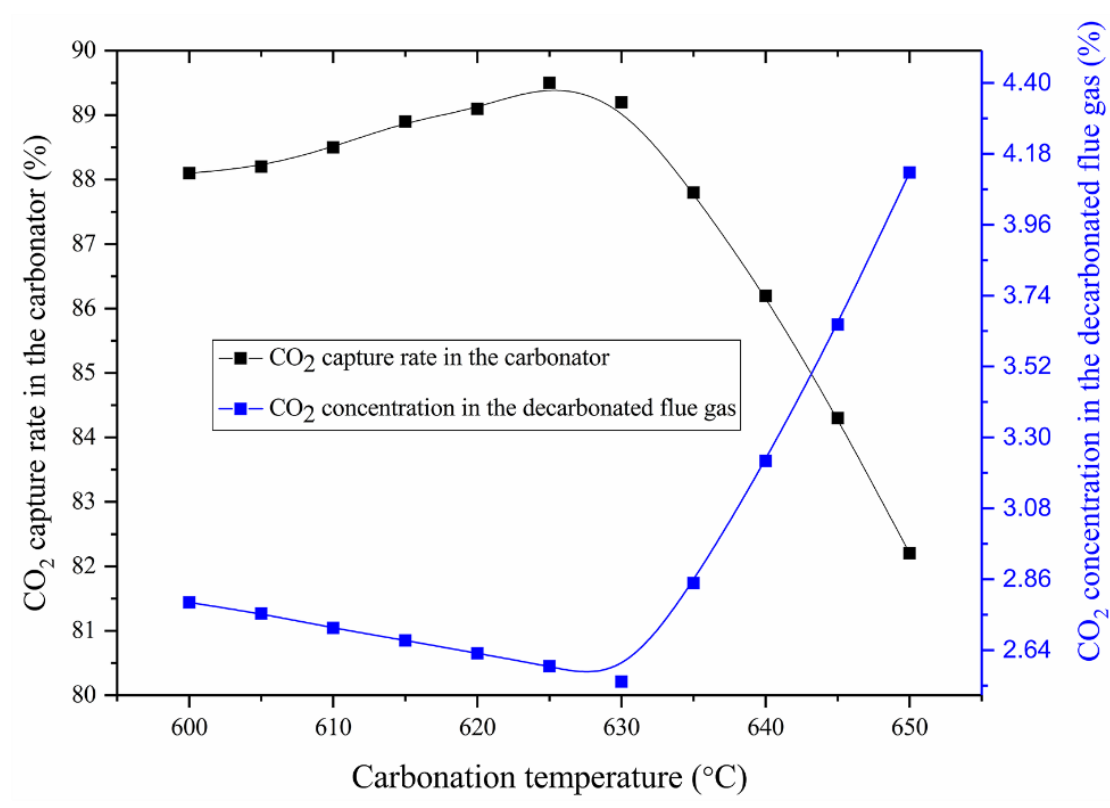

Fig. 3. $\mathrm{CO}_{2}$ capture rate in carbonator and $\mathrm{CO}_{2}$ concentrations in the decarbonated flue gas along with the changes of carbonation temperature. 


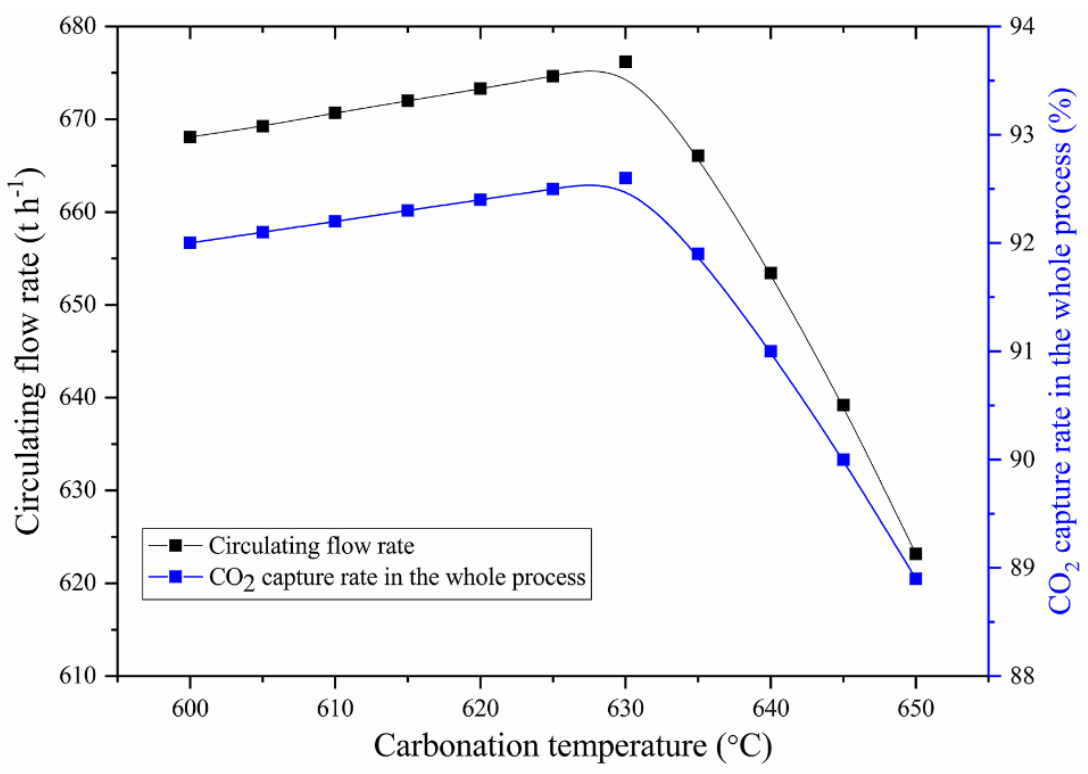

Fig. 4. $\mathrm{CO}_{2}$ capture rate of the whole process and $\mathrm{CaCO}_{3}$ circulating flow rate as the function of carbonation temperature.

\section{Effect of Calcination Temperature}

When the calcination temperature changed from 850 to $1250^{\circ} \mathrm{C}$, the carbonation temperature and coal mass flow were set as $630^{\circ} \mathrm{C}$ and $120 \mathrm{t} \mathrm{h}^{-1}$, respectively. The variation of $\mathrm{CO}_{2}$ capture rate in the carbonator and the whole process, $\mathrm{CO}_{2}$ concentrations in the decarbonated flue gas, and $\mathrm{CaCO}_{3}$ circulating flow along with the calcination temperature were calculated and analyzed.

Fig. 5 showed that the $\mathrm{CO}_{2}$ capture rate in the carbonator decreased firstly and then increased with the calcination temperature rose, on the contrary, $\mathrm{CO}_{2}$ concentrations in the decarbonated flue gas rose firstly and then dropped down. The reason for the trend was that the rising temperature caused the deactivation of sorbent which called sintering effect. Sintering can weaken $\mathrm{CO}_{2}$ capture capacity and reduce cycle times of the sorbent. When the calcination temperature was $1175^{\circ} \mathrm{C}$, the $\mathrm{CO}_{2}$ capture rate in the carbonator was only $80 \%$ and $\mathrm{CO}_{2}$ flue gas reached the highest point of $4.5 \%$. That was unacceptable for the system. However, as the calcination temperature varied from 1150 to $1250^{\circ} \mathrm{C}$, more $\mathrm{CaSO}_{4}$ decomposed into $\mathrm{CaO}$ and make-up introduced into the whole process. Thus, the more $\mathrm{CO}_{2}$ was capture in the carbonator, which increased the $\mathrm{CO}_{2}$ capture rate in the carbonator and decreased the $\mathrm{CO}_{2}$ concentration in the flue gas.

The effect of calcination temperature on the $\mathrm{CO}_{2}$ capture rate in the whole process and $\mathrm{CaCO}_{3}$ circulating flow was shown in Fig. 6. As the calcination temperature increased, the $\mathrm{CO}_{2}$ capture rate in the whole process and $\mathrm{CaCO}_{3}$ circulating flow showed the same pattern (See Fig. 5). Sintering can change and deactivate the micro-granular of the sorbent, which caused a rapid decline of the $\mathrm{CO}_{2}$ capture rate. On the other hand, when the temperature was higher than $1175^{\circ} \mathrm{C}$, the $\mathrm{CaSO}_{4}$ decomposition and make-up flow lines moved upward by indicating a sharp increment of the $\mathrm{CO}_{2}$ capture rate.

The relationship between the energy consumption and the calcination temperature was shown in Fig. 7. The energy consumption increased steadily with the calcination temperature increased. This behavior was observed because a higher calcination temperature needed more coal combustion to provide extra heat, and it increased the system load and caused much more energy consumption.

From the above-obtained results (Figs. 5, 6 and 7), it can be concluded that when the calcination was $900^{\circ} \mathrm{C}$, the $\mathrm{CO}_{2}$ capture rate in carbonator and the whole process, $\mathrm{CaCO}_{3}$ circulating flow and energy consumption were found to be $89 \%, 91 \%$, and $74.9 \mathrm{MW}$, respectively, which were the best in the process. Therefore, $900^{\circ} \mathrm{C}$ was chosen as the optimal calcination temperature.

\section{Effect of Make-up Flow}

Make-up flow $\left(\mathrm{F}_{0}\right)$ was related to $\mathrm{CO}_{2}$ concentration in the flue gas $\left(\mathrm{F}_{\mathrm{CO} 2}\right)$, therefore $\mathrm{F}_{0} / \mathrm{F}_{\mathrm{CO} 2}$ had been chosen to be a variable in further study. The carbonator and calcination temperature, coal consumption was set at $630^{\circ} \mathrm{C}, 900^{\circ} \mathrm{C}$, and $120 \mathrm{t} \mathrm{h}^{-1}$, respectively. The effect of $\mathrm{F}_{0} / \mathrm{F}_{\mathrm{CO} 2}$ on $\mathrm{CO}_{2}$ capture in the carbonator and $\mathrm{CO}_{2}$ concentration in the decarbonated flue gas were calculated and analyzed.

It can be seen from Fig. 8 that, with the increase of makeup flow, $\mathrm{CO}_{2}$ capture in the carbonator had a significant increase and $\mathrm{CO}_{2}$ concentrations in the decarbonated flue gas decreased, which indicated that more make-up flow was good for the system. On the other side, a certain level of make-up flow increase was not adequate for $\mathrm{CO}_{2}$ capture conditions. When the $\mathrm{F}_{0} / \mathrm{F}_{\mathrm{CO} 2}$ was above 0.04 , the trend of $\mathrm{CO}_{2}$ capture rate in the carbonator and $\mathrm{CO}_{2}$ concentrations in the decarbonated flue gas was stabilized gradually due to the oversaturation of $\mathrm{CaO}$ in the system. The trend showed that the appropriate amount of $\mathrm{CaCO}_{3}$ supplement was necessary, and it can update the deactivated sorbent.

Fig. 9 reflects the effect of make-up flow on the $\mathrm{CO}_{2}$ capture rate in the whole process and $\mathrm{CaCO}_{3}$ circulating flow rate, which indicated the same increase pattern when the make-up flow increased. When $\mathrm{F}_{0} / \mathrm{F}_{\mathrm{CO} 2}$ was lower than 0.04 , 


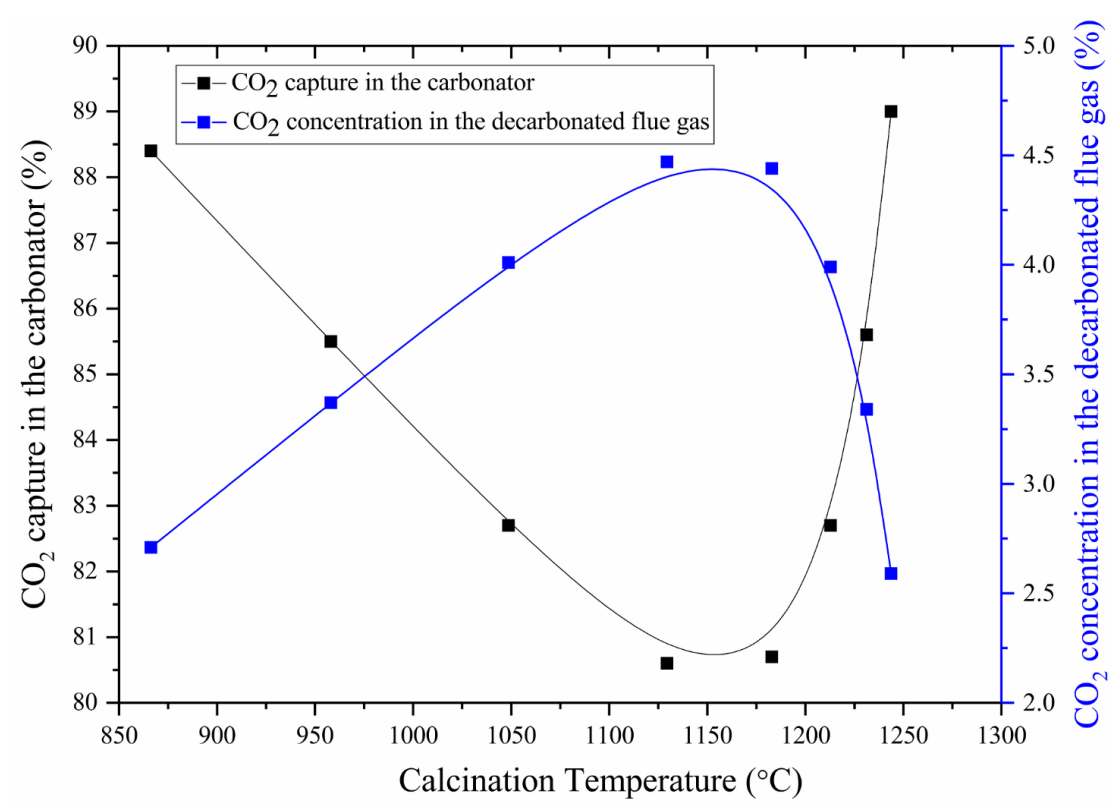

Fig. 5. $\mathrm{CO}_{2}$ capture rate in the carbonator and $\mathrm{CO}_{2}$ concentrations in the decarbonated flue gas along with the changes of calcination temperature

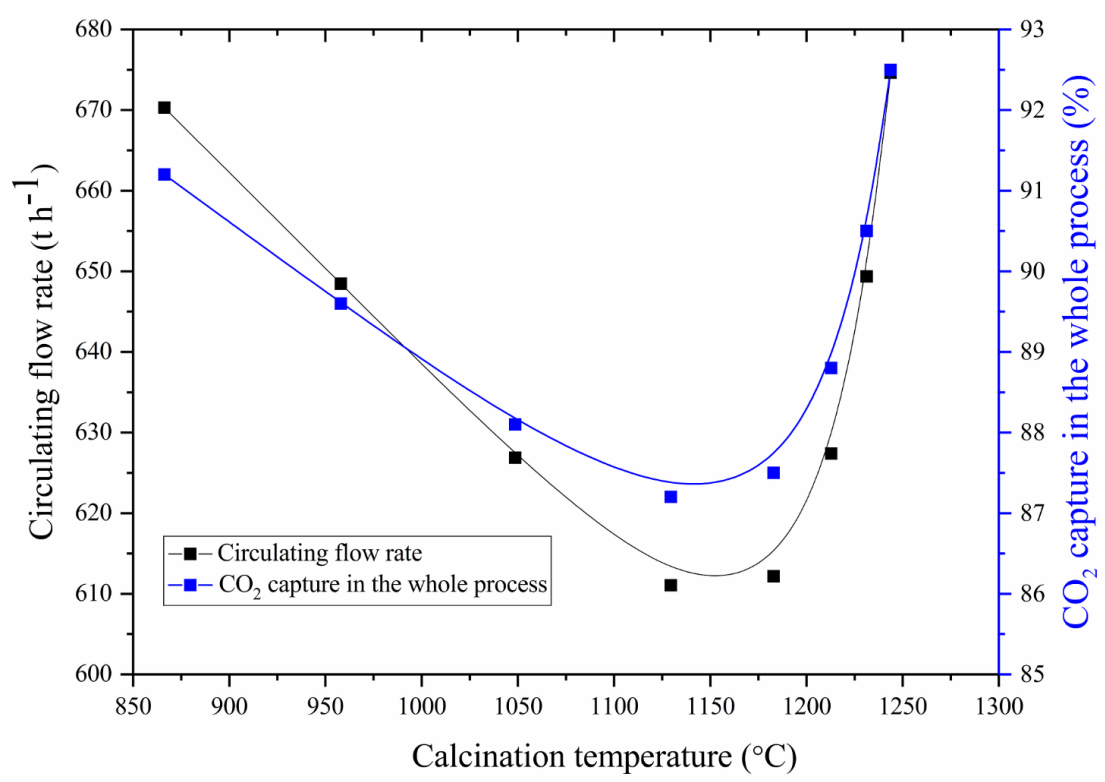

Fig. 6. $\mathrm{CO}_{2}$ capture rate in the whole process and $\mathrm{CaCO}_{3}$ circulating flow rate along with the changes of calcination temperature.

the $\mathrm{CO}_{2}$ capture rate of the whole process increased rapidly. This was observed because of the initial $\mathrm{CaCO}_{3}$ produced by carbonation was fewer than the initial circulation flow rate and when the $\mathrm{CaCO}_{3}$ stream and the make-up flow mixed, the circulating flow rate surged.

In combination with Figs. 8 and 9, when the optimal $\mathrm{F}_{0} / \mathrm{F}_{\mathrm{CO} 2}$ was 0.04 , the $\mathrm{CO}_{2}$ capture rate in the carbonator and whole process, $\mathrm{CO}_{2}$ concentration in the decarbonated flue gas and $\mathrm{CaCO}_{3}$ circulating flow rate reached the best value, which were $86.4 \%, 91.6 \%, 3.1 \%$, and $642.9 \mathrm{t} \mathrm{h}^{-1}$, respectively.

\section{Effect of Gas-solid Separation Efficiency}

When the gas-solid separation efficiency varied from 0.95 to 1.0 , the carbonation temperature, calcination temperature, and $\mathrm{F}_{0} / \mathrm{F}_{\mathrm{CO} 2}$ were set at $630^{\circ} \mathrm{C}, 900^{\circ} \mathrm{C}$, and 0.04 , respectively. The change of $\mathrm{CO}_{2}$ capture in the carbonator and $\mathrm{CO}_{2}$ concentrations in the decarbonated flue gas were calculated and analyzed.

From Figs. 10 and 11, it can be seen that the $\mathrm{CO}_{2}$ concentrations in the decarbonated flue gas and $\mathrm{CaCO}_{3}$ circulating flow rate were linear with gas-solid separation efficiency, which indicated that gas-solid separation efficiency had a great impact on the system stability. The $\mathrm{CO}_{2}$ concentrations in the decarbonated flue gas linearly decreased with the gas-solid separation efficiency increased, however, $\mathrm{CO}_{2}$ capture rate in the carbonator and the whole process and 


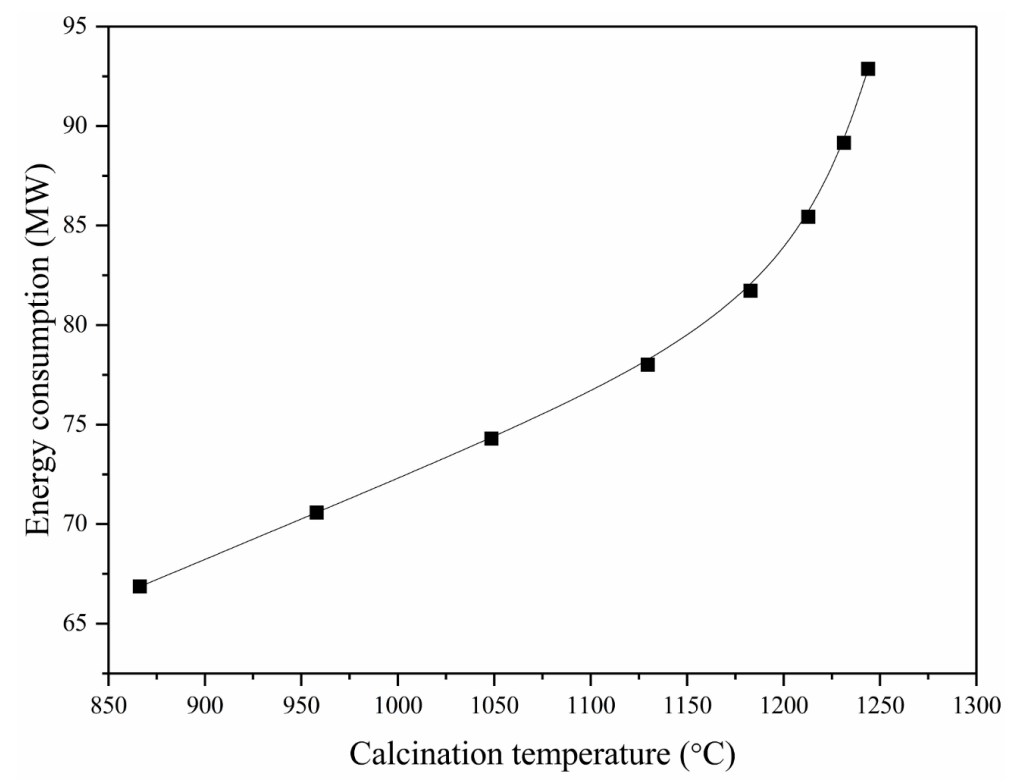

Fig. 7. Energy consumption of the calcination as a function of calcination temperature.

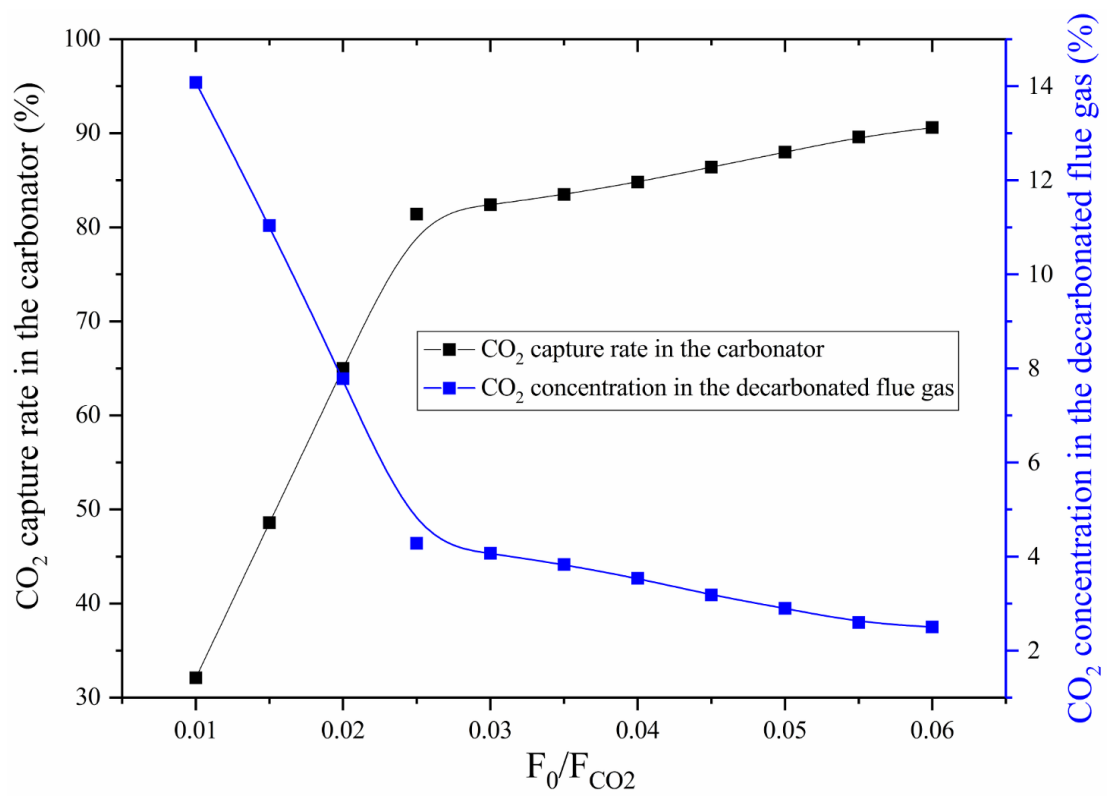

Fig. 8. $\mathrm{CO}_{2}$ capture rate in the carbonator and $\mathrm{CO}_{2}$ concentrations in the decarbonated flue gas along with the changes of make-up flow.

$\mathrm{CaCO}_{3}$ circulating flow rate showed the opposite trend. When the gas-solid separation efficiency was in the range of 0.95 to 1 , the $\mathrm{CO}_{2}$ capture rate in the carbonator increased from $87 \%$ to $89 \%$, the $\mathrm{CO} 2$ concentrations in the decarbonated flue gas decreased from $3.1 \%$ to $2.59 \%$, and the $\mathrm{CaCO}_{3}$ circulating flow also increased accordingly. Therefore, the gas-solid separation efficiency directly affected the system performance. It is observed that the higher gas-solid separation efficiency can achieve more favorable $\mathrm{CO}_{2}$ adsorption rate. Herein, the design of the cyclone should try to ensure a high gas-solid separation efficiency. When the gas-solid separation efficiency was too low, the loss of effective $\mathrm{CaO}$ sorbents increased, and the concentration of the sorbent gradually decreased after circulation, which caused $\mathrm{CO}_{2}$ cannot be captured. In the present work, we chose 1.0 as gas-solid separation efficiency.

\section{Effect of $\mathrm{SO}_{2}$ Concentration in the Flue Gas}

When the $\mathrm{SO}_{2}$ concentrations in the flue gas varied from $0.1 \%$ to $1.0 \%$, the carbonation temperature, calcination temperature, $\mathrm{F}_{0} / \mathrm{F}_{\mathrm{CO} 2}$, and gas-solid separation efficiency was set at $630^{\circ} \mathrm{C}, 900^{\circ} \mathrm{C}, 0.04$ and 1.0 , separately. The change of $\mathrm{CO}_{2}$ capture rate in the carbonator and $\mathrm{CO}_{2}$ concentrations in the decarbonated flue gas were calculated and analyzed.

It can be seen from the Fig. 12 that the $\mathrm{SO}_{2}$ concentrations in the flue gas had a great effect on the $\mathrm{CO}_{2}$ capture rate in 


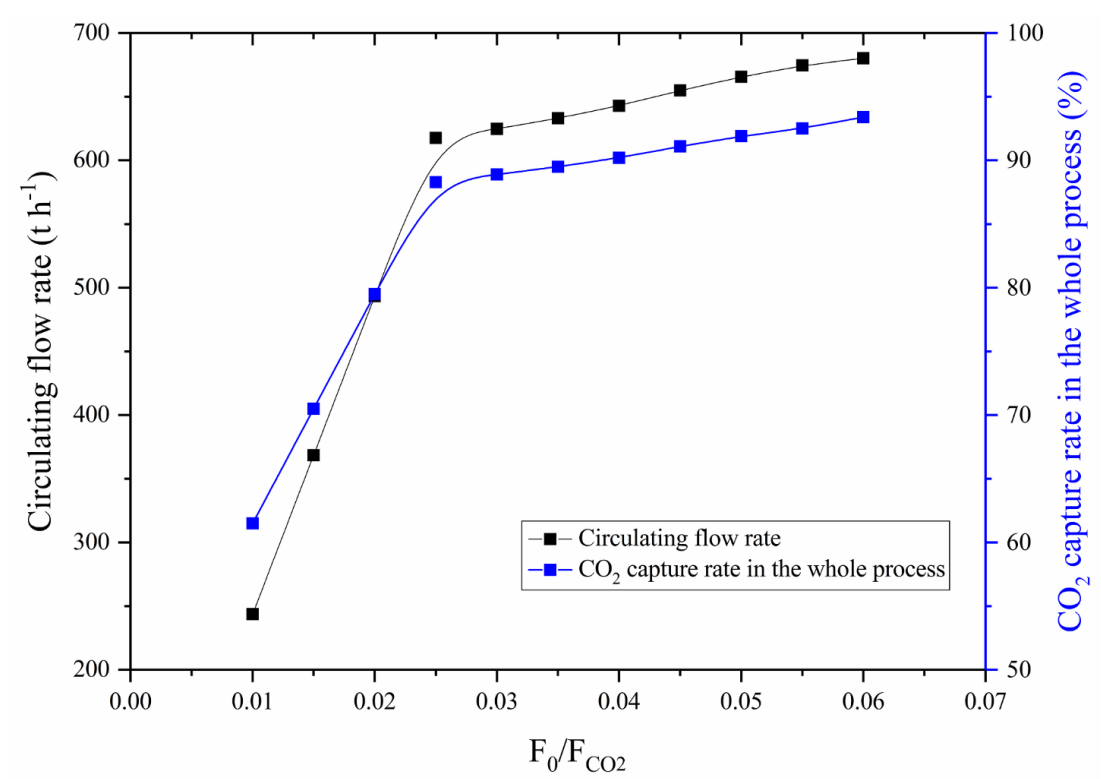

Fig. 9. $\mathrm{CO}_{2}$ capture rate in the whole process and $\mathrm{CaCO}_{3}$ circulating flow rate along with the changes of make-up flow.

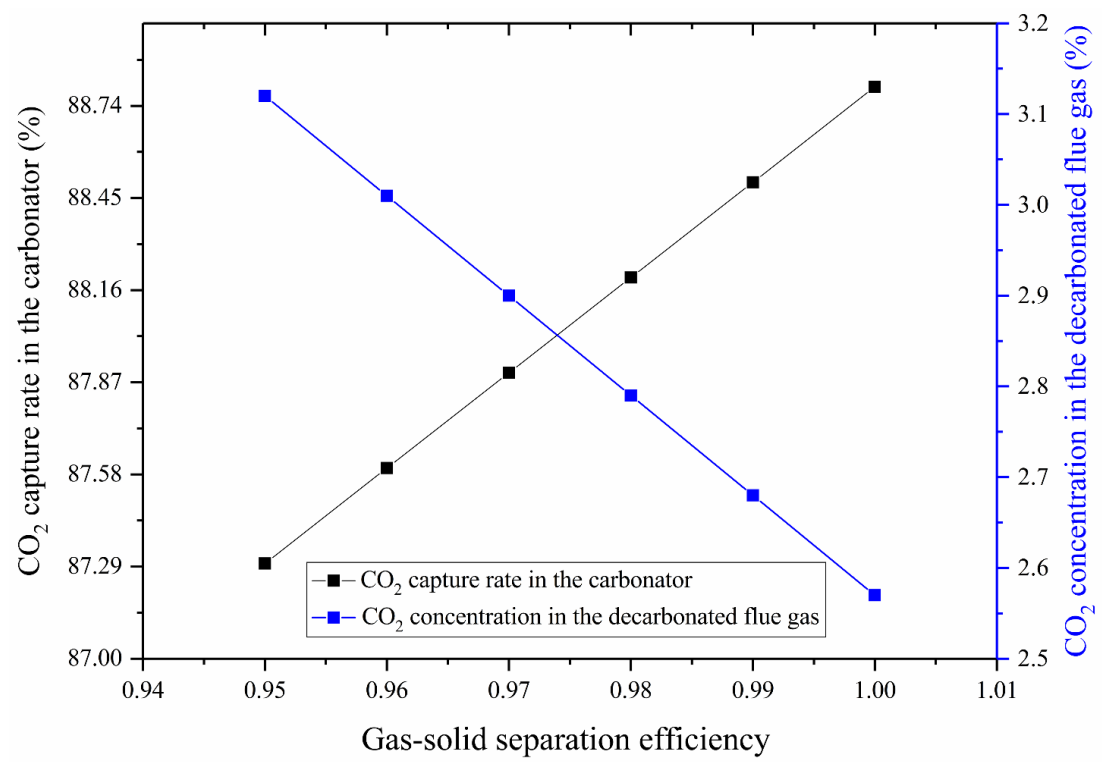

Fig. 10. $\mathrm{CO}_{2}$ capture rate in the carbonator and $\mathrm{CO}_{2}$ concentrations in the decarbonated flue gas along with the changes of gas-solid separation efficiency.

the carbonator. When the $\mathrm{SO}_{2}$ concentrations in the flue gas increased from $0.1 \%$ to $1 \%$, the $\mathrm{CO}_{2}$ capture rate in the carbonator decreased from $88.3 \%$ to $63.7 \%$, which dropped by $21.6 \%$. This trend also showed in the carbonator and $\mathrm{CaO}$ not only reacted with $\mathrm{CO}_{2}$, but with $\mathrm{SO}_{2}$, and meanwhile, the density of $\mathrm{CaSO}_{4}$ was larger than $\mathrm{CaCO}_{3}$, which was not good for $\mathrm{CO}_{2}$ diffusion process and greatly reduced the $\mathrm{CO}_{2}$ capture rate in the carbonator. Therefore, the $\mathrm{CO}_{2}$ concentrations in the decarbonated flue gas increased.

Fig. 13 showed $\mathrm{CO}_{2}$ capture rate in the whole process and $\mathrm{CaCO}_{3}$ circulating flow rate decreased with $\mathrm{SO}_{2}$ concentrations in the flue gas increased. That was because the large increase of $\mathrm{SO}_{2}$ in the flue gas, the more $\mathrm{CaO}$ was converted into $\mathrm{CaSO}_{4}$. Meanwhile, $\mathrm{CaSO}_{4}$ was not completely decomposed at $900^{\circ} \mathrm{C}$ in the calcinator. Therefore, more $\mathrm{CaSO}_{4}$ was discharged from the system, which significantly reduced the $\mathrm{CO}_{2}$ capture in the whole process and $\mathrm{CaCO}_{3}$ circulating flow.

Combining Figs. 12 and 13, when the $\mathrm{SO}_{2}$ was introduced into the system, the $\mathrm{CaO}$ sorbent reacted with $\mathrm{SO}_{2}$ firstly and then with $\mathrm{CO}_{2}$, which formed the stable $\mathrm{CaSO}_{4}$ solid and reduced circulating flow rate in the whole system. Therefore, the $\mathrm{SO}_{2}$ concentration in the flue gas had a huge influence on $\mathrm{CO}_{2}$ capture performance and to ensure the $\mathrm{CO}_{2}$ capture rate, the $\mathrm{SO}_{2}$ was mostly removed from the flue gas before came into the process and $\mathrm{SO}_{2}$ concentration in the flue gas was set as 0.1 in the work.

Under the condition that the carbonation temperature was $630^{\circ} \mathrm{C}$, the calcination temperature was $900^{\circ} \mathrm{C}$, the $\mathrm{F}_{0} / \mathrm{F}_{\mathrm{CO} 2}$ 


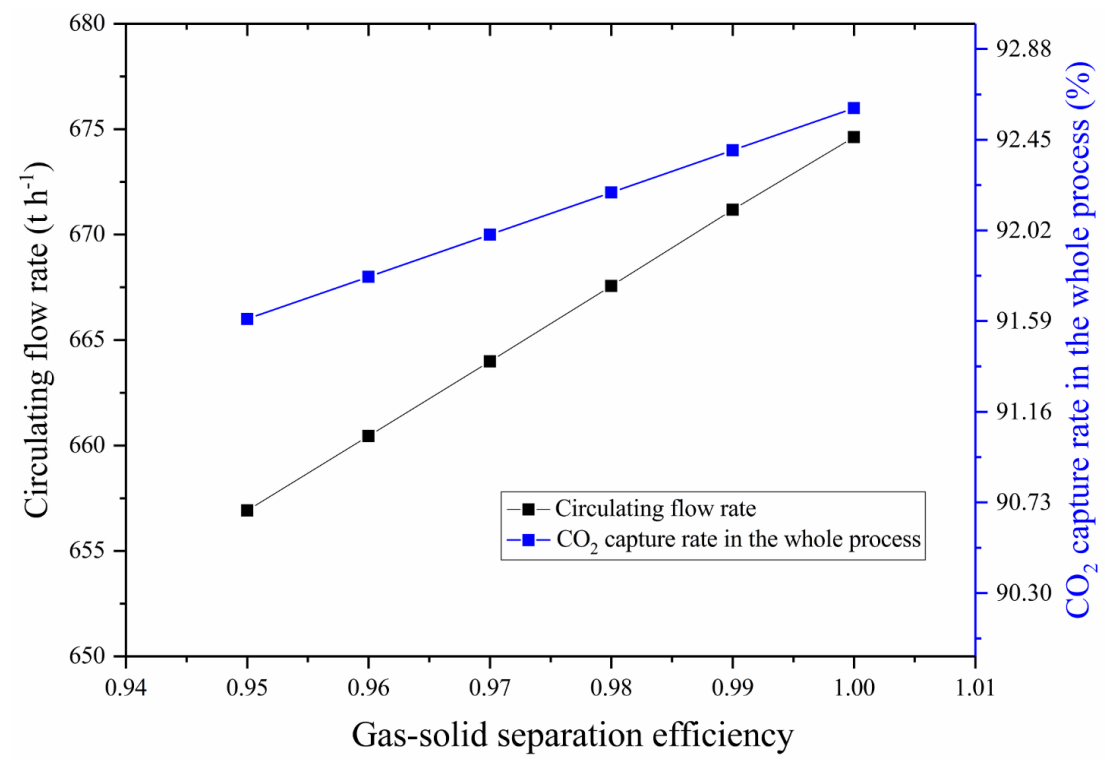

Fig. 11. $\mathrm{CO}_{2}$ capture rate in the whole process and $\mathrm{CaCO}_{3}$ circulating flow along with the changes of gas-solid separation efficiency.

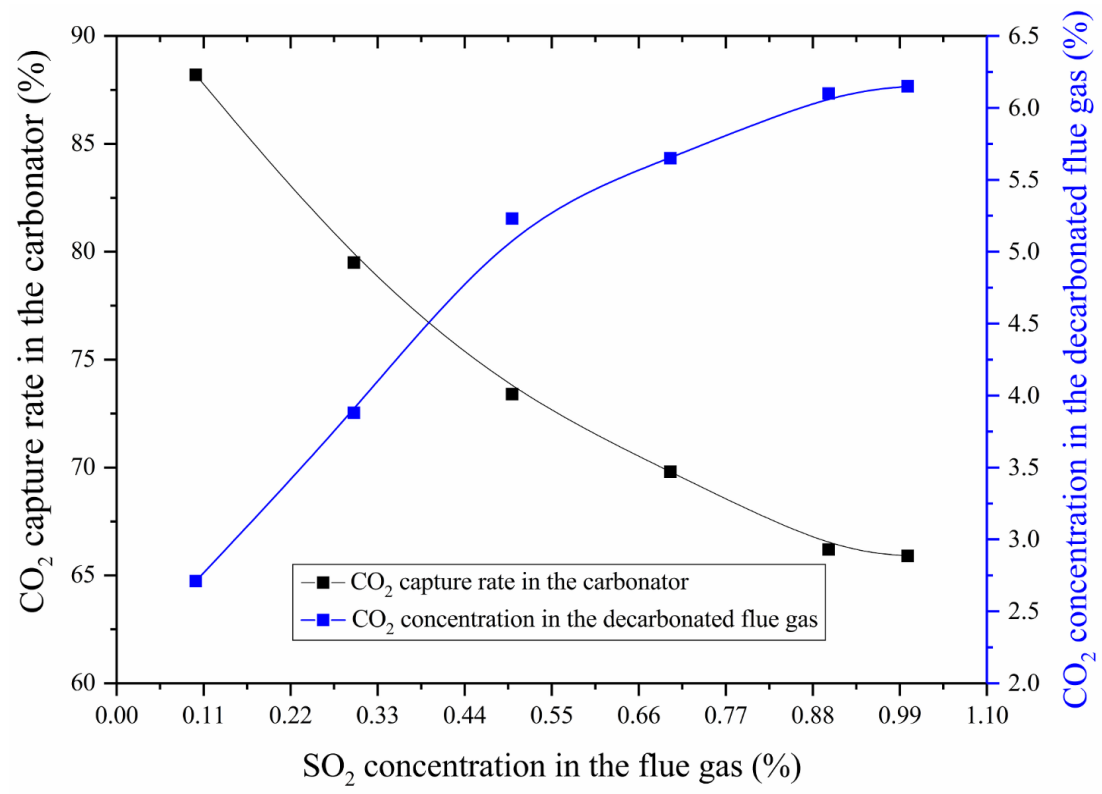

Fig. 12. $\mathrm{CO}_{2}$ capture rate in the carbonator and $\mathrm{CO}_{2}$ concentrations in the decarbonated flue gas along with the changes of $\mathrm{SO}_{2}$ concentrations in the flue gas.

was 0.04 , the gas-solid separation was 1.0 and the $\mathrm{SO}_{2}$ concentration in the flue gas was 0.1 , the simulation was carried out, see Table 3 . The results could satisfy for the $\mathrm{CO}_{2}$ capture rate of over $90 \%$ and $\mathrm{CO}_{2}$ concentration in the decarbonated flue gas was less than $4.0 \%$. By contrast, Lasheras et al. (2011) obtained $\mathrm{CO}_{2}$ capture rate of $80 \%$ in a $1052 \mathrm{MW}_{\mathrm{el}}$ coal-fired power plant. The carbonate looping used in this study can achieve above $90 \% \mathrm{CO}_{2}$ capture rate. Thus, the results of this work was reasonable.

\section{CONCLUSIONS}

In order to remove and capture $\mathrm{CO}_{2}$ from flue gas, the carbonate looping process was more suitable for operating conditions with large flow flue gas. In the work, the proposed carbonate looping process was established with ASPEN PLUS to obtain optimal parameters of the carbonate looping process. The process adopts a reversible reaction $\mathrm{CaO}+\mathrm{CO}_{2}$ $\leftrightarrow \mathrm{CaCo}_{3}$ into account and formed a circulation that would obtain higher $\mathrm{CO}_{2}$ product gas and continually recycle the sorbent. Also, due to particle attrition and sintering of $\mathrm{CaO}$, the make-up flow should be introduced into the system. Meanwhile, the sensitivity analysis of several parameters was conducted and the optimal parameters were selected and listed in Table 3. The main results of this work were as follows: 


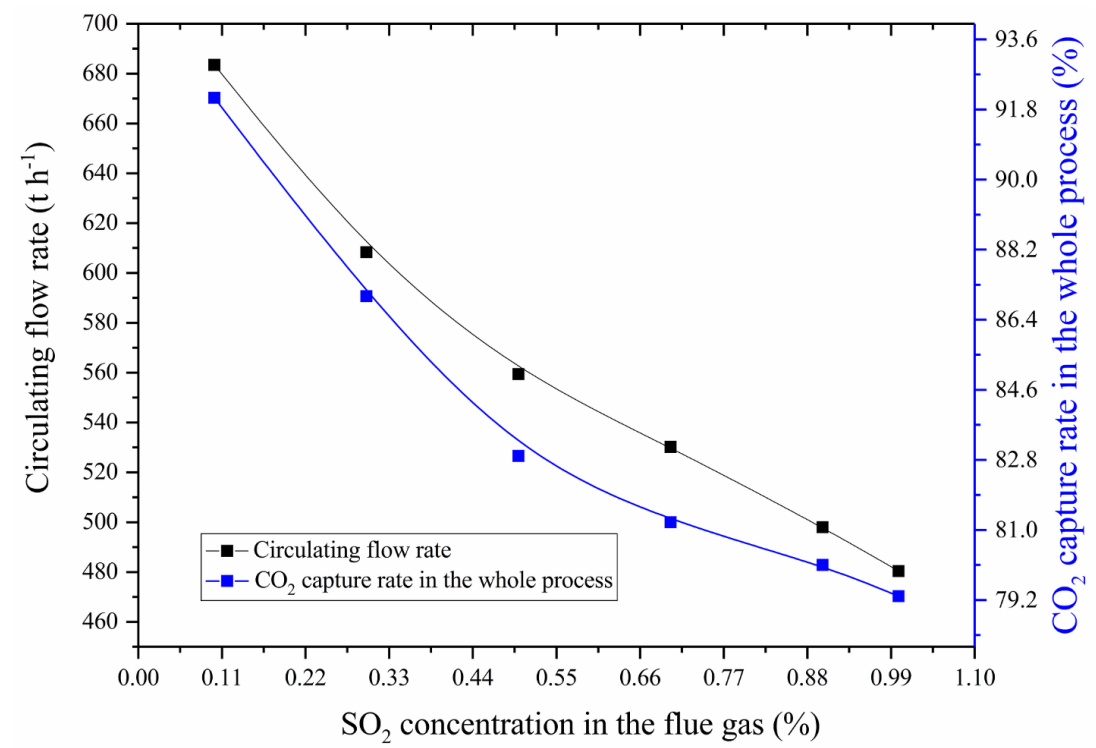

Fig. 13. $\mathrm{CO}_{2}$ capture rate in the whole process and $\mathrm{CaCO}_{3}$ circulating flow rate along with the changes of $\mathrm{SO}_{2}$ concentrations in the flue gas.

Table 3. Summary of carbonate looping process.

\begin{tabular}{ll}
\hline Results parameters & Numerical value \\
\hline Carbonation temperature $\left({ }^{\circ} \mathrm{C}\right)$ & 630 \\
Calcination temperature $\left({ }^{\circ} \mathrm{C}\right)$ & 900 \\
$\mathrm{~F}_{0} / \mathrm{F}_{\mathrm{CO} 2}$ & 0.04 \\
Gas-solid separation efficiency & 1.0 \\
$\mathrm{SO}_{2}$ concentration in the flue gas & 0.1 \\
\hline
\end{tabular}

1. The proper temperature increase of carbonate and calcination would be beneficial to the reaction, which can increase the $\mathrm{CO}_{2}$ capture rate. However, the over-high temperature can cause deactivation of sorbents and decrease of the solid circulating flow;

2. The increase of make-up flow increased the solid circulating flow and the activated $\mathrm{CaO}$ sorbent which significantly promoted $\mathrm{CO}_{2}$ capture rate. when the $\mathrm{F}_{0} / \mathrm{F}_{\mathrm{CO} 2}$ was 0.04 , the $\mathrm{CO}_{2}$ capture rate in the whole system was $91.6 \%$ and reached the highest value;

3. The gas-solid efficiency and $\mathrm{SO}_{2}$ concentrations in the flue gas both had huge influence on the $\mathrm{CO}_{2}$ capture rate. When the gas-solid efficiency decreased from 1.0 to 0.95 , the $\mathrm{CO}_{2}$ capture rate dropped by $2 \%$. Meanwhile, as the $\mathrm{SO}_{2}$ concentrations in the flue gas increased from $0.1 \%$ to $1.0 \%$, the $\mathrm{CO}_{2}$ capture rate decreased by $21.6 \%$;

4. When the carbonation temperature was $630^{\circ} \mathrm{C}$, the calcination temperature was $900^{\circ} \mathrm{C}$, the $\mathrm{F}_{0} / \mathrm{F}_{\mathrm{CO} 2}$ was 0.04 , the gas-solid separation was 1.0 and the $\mathrm{SO}_{2}$ concentration in the flue gas was 0.1 , the target of the $\mathrm{CO}_{2}$ capture of $>90 \%$ and $\mathrm{CO}_{2}$ concentrations in the decarbonated flue gas $<4.0 \%$ could be achieved.

The simulation results were applicable to the current situation of most stations which provide a good example for the utilization of $\mathrm{CO}_{2}$ capture in power plants. However, there were also some important parameters, such as pressure drop, solid fraction, superficial velocity of carbonator, and so on, which we did not discuss in the work. These parameters also play an indispensable role in system performance, which will be a challenge for us in the future.

\section{ACKNOWLEDGMENTS}

This work was supported by the Department of Science $\&$ Technology of Shandong Province (No. ZR2018LB025).

\section{REFERENCES}

Abad, A., Adánez, J., García-Labiano, F., de Diego, L. F., Gayán, P. and Celaya, J. (2007). Mapping of the range of operational conditions for $\mathrm{Cu}-, \mathrm{Fe}-$, and Ni-based oxygen carriers in chemical-looping combustion. Chem. Eng. Sci. 62: 533-549. https://doi.org/10.1016/j.ces.200 6.09.019

Alam, S., Kumar, J.P., Rani, K.Y. and Sumana, C. (2020). Comparative assessment of performances of different oxygen carriers in a chemical looping combustion coupled intensifified reforming process through simulation study. $J$. Cleaner Prod. 262: 121-146. https://doi.org/10.1016/j.jcl epro.2020.121146

Alonso, M., Rodriguez, N., Gonzalez, B., Grasa, G., Murillo, R. and Abanades, J.C. (2010). Carbon dioxide capture from combustion flue gases with a calcium oxide chemical loop. Experimental results and process development. Int. J. Greenhouse Gas Control. 4: 167173. https://doi.org/10.1016/j.ijggc.2009.10.004

Alonso, M., Arias, B., Fernandez, J.R., Bughin, O. and Abanades, C. (2018). Measuring attrition properties of calcium looping materials in a $30 \mathrm{~kW}$ pilot plant. Powder Technol. 336: 273-281. https://doi.org/10.1016/j.powtec. 2018.06.011

Atsonios, K., Zeneli, M., Nikolopoulos, N., Grammelis, P. and Kakaras, E. (2015). Calcium looping process 
simulation based on an advanced thermodynamic model combined with CFD analysis. Fuel 153: 370-381. https://doi.org/10.1016/j.fuel.2015.03.014

Charitos, A., Hawthorne, C., Bidwe, A.R., Sivalingam, S., Schuster, A., Spliethoff, H. and Scheffknecht, G. (2010). Parametric investigation of the calcium looping process for $\mathrm{CO}_{2}$ capture in a $10 \mathrm{~kW}_{\text {th }}$ dual fluidized bed. Int. J. Greenhouse Gas Control. 4: 776-784. https://doi.org/10. 1016/j.ijggc.2010.04.009

Cheng, L., Ji, D., He, J., Li, L., Du, L., Cui, Y., Zhang, H., Zhou, L., Li, Z., Zhou, Y., Miao, S., Gong, Z. and Wang, Y. (2019). Characteristics of air pollutants and greenhouse gases at a regional background station in southwestern China. Aerosol Air Qual. Res. 19: 1007-1023. https://doi.org/10.4209/aaqr.2018.11.0397

Diego, M.E., Arias, B. and Abanades, J.C. (2017). Evolution of the $\mathrm{CO}_{2}$ carrying capacity of $\mathrm{CaO}$ particles in a large calcium looping pilot plant. Int. J. Greenhouse Gas Control. 62: 69-75. https://doi.org/10.1016/j.ijggc.2017. 04.005

Hilz, J., Haaf, M., Helbig, M., Lindqvist, N., Strohle, J. and Epple, B. (2019). Scale-up of the carbonate looping process to a $20 \mathrm{MW}_{\text {th }}$ pilot plant based on long-term pilot tests. Int. J. Greenhouse Gas Control. 88: 332-341. https://doi.org/10.1016/j.ijggc.2019.04.026

Hoeftberger, D. and Karl, J. (2016). The indirectly heated carbonate looping process for $\mathrm{CO}_{2}$ capture - A concept with heat pipe heat exchanger. J. Energy Resour. Technol. 138: 042211. https://doi.org/10.1115/1.4033302

Huang, Y., Su, W., Wang, R. and Zhao, T. (2019). Removal of typical industrial gaseous pollutants: From carbon, zeolite, and metal-organic frameworks to molecularly imprinted adsorbents. Aerosol Air Qual. Res. 19: 2130 2150. https://doi.org/10.4209/aaqr.2019.04.0215

Jia, L., Hughes, R., Lu, D., Anthony, E. and Lau, I. (2007). Attrition of calcining limestones in circulating fluidizedbed systems. Ind. Eng. Chem. Res. 46: 5199-5209. https://doi.org/10.1021/ie061212t

Jiang, Q., Wang, F. and Sun, Y. (2019). Analysis of chemical composition, source and processing characteristics of submicron aerosol during the summer in Beijing, China. Aerosol Air Qual. Res. 19: 1450-1462. https://doi.org/10. 4209/aaqr.2018.12.0480

Lasheras, A., Strohle, J., Galloy, A. and Epple, B. (2011). Carbonate looping process simulation using 1D fludized bed model for the carbonator. Int. J. Greenhouse Gas Control. 5: 686-693. https://doi.org/10.1016/j.ijggc.2011. 01.005

Leion, H., Mattisson, T. and Lyngfelt, A. (2008). Solid fuels in chemical-looping combustion. Int. J. Greenhouse Gas Control. 2: 180-193. https://doi.org/10.1016/S17505836(07)00117-X

Li, L., Zhao, N., Wei, W. and Sun, Y.H. (2013). A review of research progress on $\mathrm{CO}_{2}$ capture, storage, and utilization in Chinese Academy of Sciences. Fuel 108: 112-130. https://doi.org/10.1016/j.fuel.2011.08.022

Liang, Z. (Henry), Rongwong, W., Liu, H., Fu, K., Gao, H., Cao, F., Zhang, R., Sema, T., Henni, A., Sumon, K., Nath,
D., Gelowitz, D., Srisang, W., Saiwan, C., Benamor, A., Al-Marri, M., Shi, H., Supap, T., Chan, C., ... Tontiwachwuthikul, P. (2015). Recent progress and new development in post-combustion carbon-capture technology with amine based solvents. Int. J. Greenhouse Gas Control. 40: 26-54. https://doi.org/10.1016/j.ijggc.2015.06.017

Liu, B., Yang, X., Wang, T., Zhang, M. and Chiang, P.C. (2019a). $\mathrm{CO}_{2}$ separation by using a three-stage membrane process. Aerosol Air Qual. Res. 19: 2917-2928. https://doi.org/10.4209/aaqr.2019.10.0519

Liu, B., Zhang, M., Yang, X. and Ting, W. (2019b). Simulation and energy analysis of $\mathrm{CO}_{2}$ capture from $\mathrm{CO}_{2}$ EOR extraction gas using cryogenic fractionation. $J$. Taiwan Inst. Chem. Eng. 103: 67-74. https://doi.org/10.1 016/j.jtice.2019.07.008

Liu, B., Yang, X., Chiang, P.C. and Ting, W. (2020). Energy consumption analysis of cryogenic-membrane hybrid process for $\mathrm{CO}_{2}$ capture from $\mathrm{CO}_{2}$-EOR extraction gas. Aerosol Air Qual. Res. 20: 820-832. https://doi.org/10.42 09/aaqr.2020.02.0047

Martinez, I., Arias, B., Grasa, G.S. and Abanades, J.C. (2018). $\mathrm{CO}_{2}$ capture in existing power plants using second generation Ca-looping systems firing biomass in the calciner. J. Cleaner Prod. 187: 638-649. https://doi.org/1 0.1016/j.jclepro.2018.03.189

Oh, S.Y., Binns, M., Cho, H. and Kim, J.K. (2016). Energy minimization of MEA-based $\mathrm{CO}_{2}$ capture process. Appl. Energy 169: 353-362. https://doi.org/10.1016/j.apenergy. 2016.02.046

Pan, S.Y., Shah, K.J., Chen, Y.H., Wang, M.H. and Chiang, P.C. (2017). Deployment of accelerated carbonation using alkaline solid wastes for carbon mineralization and utilization toward a circular economy. ACS Sustainable Chem. Eng. 5: 6429-6437. https://doi.org/10.1021/acssus chemeng. 7b00291

Porter, R.T.J., Fairweather, M., Pourkashanian, M. and Woolley, R.M. (2015). The range and level of impurities in $\mathrm{CO}_{2}$ streams from different carbon capture sources. Int. J. Greenhouse Gas Control. 36: 161-174. https://doi.org/ 10.1016/j.ijggc.2015.02.016

Reitz, M., Junk, M., Strohle, J. and Epple, B. (2016). Design and operation of a $300 \mathrm{~kW}_{\text {th }}$ indirectly heated carbonate looping pilot plant. Int. J. Greenhouse Gas Control. 54: 272-281. https://doi.org/10.1016/j.ijggc.2016.09.016

Romano, M. (2009). Coal-fired power plant with calcium oxide carbonation for postcombustion $\mathrm{CO}_{2}$ capture. Energy Procedia 1: 1099-1106. https://doi.org/10.1016/j. egypro.2009.01.145

Safarian, S., Unnthorsson, R. and Richter, C. (2020). Effect of coronavirus disease 2019 on $\mathrm{CO}_{2}$ emission in the world. Aerosol Air Qual. Res. 20: 1197-1203. https://doi.org/10.4209/aaqr.2020.04.0151

Safdarnejad, S.M., Hedengren, J.D. and Baxter, L.L. (2016). Dynamic optimization of a hybrid system of energystoring cryogenic carbon capture and a baseline power generation unit. Appl. Energy 172: 66-79. https://doi.org/ 10.1016/j.apenergy.2016.03.074

Shah, K.J. and Imae, T. (2016). Analytical investigation of specific adsorption kinetics of $\mathrm{CO}_{2}$ gas on dendrimer 
loaded in organoclays. Chem. Eng. J. 283: 1366-1373. https://doi.org/10.1016/j.cej.2015.08.113

Shimizu, T., Hirama, T., Hosoda, H., Kitano, K., Inagaki, M. and Tejima, K. (1999). A twin fluid-bed reactor for removal of $\mathrm{CO}_{2}$ from combustion processes. Chem. Eng. Res. Des. 77: 62-68. https://doi.org/10.1205/0263876995 25882

Solares, R.A.A. and Wood, J. (2020). A parametric study of process design and cycle configurations for pre-combustion PSA applied to NGCC power plants. Chem. Eng. Res. Des. 160: 141-153. https://doi.org/10.1016/j.cherd.2020. 04.039

Strohle, J., Junk, M., Kremer, J., Galloy, A. and Epple, B. (2014). Carbonate looping experiments in a $1 \mathrm{MW}_{\text {th }}$ pilot and model validation. Fuel 127: 13-22. https://doi.org/10. 1016/j.fuel.2013.12.043

Symonds, R.T., Lu, D.Y., Hughes, R.W., Anthony, E.J. and Macchi, A. (2009). $\mathrm{CO}_{2}$ Capture from simulated syngas via cyclic carbonation/calcination for a naturally occurring limestone: Pilot-plant testing. Ind. Eng. Chem. Res. 48: 8431-8440. https://doi.org/10.1021/ie900645x

Symonds, R.T., Lu, D.Y., Macchi, A., Hughes, R.W. and Anthony, E.J. (2017). The effect of $\mathrm{HCl}$ and steam om cyclic $\mathrm{CO}_{2}$ capture performance in calcium looping systems. Chem. Eng. Sci. 2017. https://doi.org/10.1016/j. ces.2017.08.019

Tritippayanon, R., Piemjaiswang, R., Piumsomboon, P. and Chalermsinsuwan, B. (2019) Computational fluid dynamics of sulfur dioxide and carbon dioxide capture using mixed feeding of calcium carbonate/calcium oxide in an industrial scale circulating fluidized bed boiler. Appl. Energy 250:
493-502. https://doi.org/10.1016/j.apenergy.2019.05.069 Yang, X., Li, Z., Liu, Y., Xing, Y., Wei, J., Yang, B., Zhang, C., Yang, R.T. and Tsai, C.J. (2019). Research progress of gaseous polycyclic aromatic hydrocarbons purification by adsorption. Aerosol Air Qual. Res. 19: 911-924. https://doi.org/10.4209/aaqr.2018.11.0398

Yuan, L.C., Pfotenhauer, J.M. and Qiu, L.M. (2014). A preliminary investigation of cryogenic $\mathrm{CO}_{2}$ capture utilizing a reverse Brayton Cycle. AIP Conference Proceedings (Vol. 1573, No. 1, pp. 1107-1114). American Institute of Physics. Zhang, L.Y., Shen, Q., Wang, M.Q., Sun, N., Wei, W., Lei, Y. and Wang, Y.J. (2019). Driving factors and predictions of $\mathrm{CO}_{2}$ emission in China's coal chemical industry. $J$. Cleaner Prod. 210: 1131-1140. https://doi.org/10.1016/j. jclepro.2018.10.352

Zhang, W., Li, Y., Duan, L., Ma, X., Wang, Z. and Liu, C. (2016). Attrition behavior of calcium-based waste during $\mathrm{CO}_{2}$ capture cycles using calcium looping in a fluidized bed reactor. Chem. Eng. Res. Des. 109: 806-815. https://doi.org/10.1016/j.cherd.2016.04.003

Zhao, X., Ji, G., Liu, W., He, X., Anthony, E.J. and Zhao, M. (2018). Mesoporous $\mathrm{MgO}$ promoted with $\mathrm{NaNO}_{3} / \mathrm{NaNO}_{2}$ for rapid and high-capacity $\mathrm{CO}_{2}$ capture at moderate temperatures. Chem. Eng. J. 332: 216-226. https://doi.org/ 10.1016/j.cej.2017.09.068

Received for review, July 24, 2020 Revised, September 14, 2020 Accepted, September 15, 2020 